\title{
Denetim Senaryolarının Muhasebe Denetimindeki Önemi
}

\section{Importance of Mock Audits in Auditing}

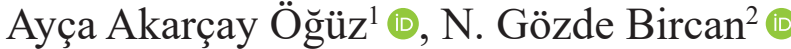 \\ ${ }^{1}$ Doç.Dr., Marmara Üniversitesi İşletme Fakültesi, İşletme Bölümü, Muhasebe Ana Bilim Dalı, İstanbul, Türkiye. Eposta: aakarcay@marmara.edu.tr \\ ${ }^{2}$ Doktora Öğrencisi, İstanbul Üniversitesi, Sosyal Bilimler Enstitüsü, İşletme Ana Bilim Dalı, Muhasebe Bilim Dalı, İstanbul, Türkiye. \\ Eposta: g.bircan@iku.edu.tr \\ ORCID: A.A.Ö. 0000-0002-2682-8741; N.G.B. 0000-0002-0217-6339
}

\section{öz}

Denetim senaryoları veya prova denetimler, son yıllarda işletmelerde yaşanan hile skandalları ve özellikle muhasebe sistemleri içerisinde artan çeşitli hile ve usulsüzlük olayları sebebiyle giderek önem kazanan yeni denetim yaklaşımlarından biridir. Bir denetim provası veya ön hazırlık denetimi olarak da nitelendirilebilen denetim senaryoları sayesinde, muhasebe sistemleri içerisinde gerçekleşebilecek uygunsuzluklar veya usulsüz işlemler önceden senaryolaştırılarak keşfedilebilmekte, böylelikle denetim faaliyetlerinde proaktiflik sağlanabilmektedir. Denetimin konusuna ve incelenen süreçlere özel olarak tasarlanan farklı denetim senaryoları aracılığıyla işletmelerin muhasebe sistemleri içerisinde erken bir uyarı mekanizması oluşturularak hile ve usulsüzlük gibi riskler de etkin şekilde yönetilebilmektedir. Çalışmamızda, günümüz Dünyasında senaryo denetimlerinin ve denetimde senaryo planlamacı yaklaşımın, muhasebe denetimindeki gerekliliği ve denetim faaliyetlerinin etkinliği açısından taşıdığı önemden hareketle denetim biliminde senaryo planlamacı yaklaşım ve senaryo denetimine dair teorik bilgilerin literatüre kazandırılması amaçlanmıştır.

Anahtar kelimeler: Denetim, Senaryo, Prova Denetimi, Muhasebe

\section{ABSTRACT}

Audit scenarios or mock audits are one of the new audit approaches gaining importance, due to an increasing number of frauds and irregularities in organizational accounting systems in recent years. Specifically, such inaccuracies/irregularities can be discovered in advance by writing scripts through mock audit scenarios. In addition, fraud risks and irregularities can be effectively managed with an early alarm system in organizational accounting systems that generates different audit scenarios and related processes. Thus, this study examined the necessity and importance of audit scenarios and scenario planning in order to enhance the methodology regarding accounting and the effectiveness of auditing processes in today's world.

Keywords: Auditing, Scenario, Mock Audits, Accounting

Başvuru/Submitted: 05.02.2021 Revizyon Talebi/Revision Requested: 17.03.2021 Son Revizyon/Last Revision Received: 19.03.2021 Kabul/Accepted: 14.05.2021 Sorumlu yazar/Corresponding author: N. Gözde Bircan / g.bircan@iku.edu.tr 


\section{Extended Abstract}

Audit scenarios and mock audits are one of the new audit approaches in today's world. However, its paradigm dates back to ancient times, since humans have always temperamentally experienced "what-if" scenarios. Although there is no generally accepted definition of "mock audits" in the literature, such audits can be likened to theater. For example, the scenarios and audiences in theater can be understood as audit matters and auditors/auditees, respectively. In general, mock audits not only allow organizations to fix potential audit problems and inaccuracies in advance, but they can also be utilized to determine fraud risks and control deficiences in a more effective way.

As is well known, uncertainties, chaos environments, financial crises, and fraud scandals in organizational accounting systems are major risks. Thus, using real-time data and estimating it as close as possible to actual scenarios is the only way to deal with such risks. In this regard, mock audits are one of the most effective tools for considering uncertainties and chaos environments, since audit-related matters can be foreseen, planned, and discovered in a proactive, risk-based way, in addition to standard audit functions such as reporting, testing, and reviewing.

In general, mock audits create realistic scenarios about the future and estimate potential audit matters when there is nothing subject to an audit, whereas traditional audits perform certain actions in real terms. Specifically, in mock audits, the auditees can be one-step ahead by preparing for future formal audits. At the same time, auditors who participate in mock audits can develop their skills and creativity, and make up any deficiencies in regard to their professional development.

Although there are numerous advantages of mock audits, they are not commonly performed by many organizations, since such audits are generally perceived as extra audits with additional costs. However, from a cost-benefit perspective, the advantages of mock audits outweigh the costs. Meanwhile, the coverage of such audits in the audit literature is still limited. Therefore, this study examined the necessity and importance of audit scenarios and scenario planning in order to enhance the methodology regarding accounting and the effectiveness of auditing processes in today's world. It also focused on the advantages and disadvantages of mock audits for both auditees and auditors in order to raise awareness about this approach. 


\section{Giriş}

Günümüz Dünyasındaki belirsizlik ve kriz ortamı ile işletmelerin içerisinde bulunduğu sürekli değişim ve dönüşüm ortamı, denetim biliminde geleneksel (klasik) yaklaşımların yetersiz kalmasına neden olarak geleceği öngörebilen, planlayabilen, denetime konu unsurları önceden keşfedebilen, proaktif, risk odaklı ve kestirimsel nitelikteki yeni denetim yaklaşımlarına duyulan ihtiyacı ortaya çıkarmıştır. Yeni Dünyanın koşulları, sadece işletme yönetimleri açısından değil denetim mesleği açısından da çeviklik, hızlı adaptasyon ve yılmazlık kavramlarına uygun şekilde ileride meydana gelebilecek olaylara karşı hazırlıklı olmanın ötesinde, geleceği çeşitli senaryolar aracılığı ile şimdiden kurgulanabilir hale getirebilmeyi veya tasarlayabilmeyi gerektirmektedir. Senaryo denetimleri veya prova denetimler, denetim mesleğinde bu ihtiyaçtan dolayı ortaya çıkmış yeni denetim yaklaşımlarından biridir.

Değişen Dünya dinamikleri ve bu dinamiklerin sebep olduğu krizler sebebiyle işletmeler açısından belirsizlik ortamı giderek büyümektedir. Belirsizlik ve krizler ile birlikte işletmelerin iş yapış şekilleri, operasyonel süreçleri, müşteriler, tedarikçiler kredi kurumları vb. gibi işletme ile ilgili taraflarla olan ilişkileri de sürekli ve hızlı bir şekilde değişerek işletme içerisinde bir kaos ortamının oluşmasına neden olmaktadır. Böyle bir ortamda ise işletmelerin muhasebe sistemlerinin bozulması kolaylaşmakta ve muhasebe sistemleri içerisinde hata, hile veya çeşitli usulsüzlüklerin meydana gelme riski artmaktadır. Söz konusu hata, hile ve usulsüzlüklerin meydana gelme riskinin azaltılması ve muhasebe sistemlerinin güvenilirliğinin sağlanması için işletmelerin söz konusu hata ve hileler ortaya çıkmadan önce hata veya hile varmış gibi denetim mekanizmalarını harekete geçirerek geleceğe yönelik farklı senaryolar tasarlaması ve bu senaryoların sonuçlarını analiz etmesi gerekmektedir. Örneğin; tüm Dünyanın içinden geçmiş olduğu COVID-19 küresel salgını ile birlikte işletmeler açısından her geçen gün belirsizliklerin artması işletmelerin, COVID-19'un gelecekte muhasebe sistemlerinde meydana getirebileceği hata, hile, usulsüzlük vb. gibi riskleri şimdiden farklı senaryolarla kurgulama ve denetleme konusunda harekete geçmesini zorunlu kılmıştır. Diğer bir deyişle işletmeler, salgının etkisi ile organizasyonları içerisinde yaşanabilecek suistimalleri önceden senaryolaştırma çabasına girişmişlerdir. Bunun en büyük sebebi, COVID-19 vb. gibi küresel ekonomik krizlerle birlikte işletmelerin muhasebe sistemleri içerisindeki karmaşanın ve kaosun artmasıdır. Karmaşık muhasebe sistemleri içerisinde hem kişileri hile yapmaya iten baskı unsurları artmakta hem de işletme içi kontroller güçleşmekte böylelikle hileye elverişli bir fırsat ortamı oluşmaktadır. Buna bağlı olarak işletmelerde hilelerin gerçekleşme olasılığı ile söz konusu hile ve usulsüzlüklerin işletmelere verebileceği zararların şiddeti de artmaktadır. Ayrıca son yıllarda teknolojide meydana gelen yeni gelişmeler de, işletmelerin muhasebe sistemleri içerisinde söz konusu belirsizliklerin yarattığı firsat ortamını destekleyerek işletmelerde hile ve usulsüzlüklerin gerçekleştirilmesini kolaylaştırmaktadır.

Günümüzde işletmelerin kriz, belirsizlik ve teknolojik değişimlerin yarattığ 1 fırsat ortamından faydalanarak hile ve usulsüzlükleri gerçekleştirebilecek potansiyel hilekâr adı verilen kişi veya kişilerden bir adım önde davranarak bir hilekâr gibi düşünmesi, potansiyel hile ve usulsüzlük durumlarını önceden keşfetmesi, oluşabilecek hile ve usulsüzlük olaylarını önceden tasarlaması ve potansiyel hile ve usulsüzlük durumlarına karşı önceden harekete geçmesi gerekmektedir. Bu ise ancak ortada henüz denetlenmesi gereken bir olgu yok iken denetlenmesi gereken bir olgu varmış varsayımıyla hareket eden ve farklı gelecekler için farklı senaryolar tasarlayabilen yeni bir denetim anlayışı ile mümkün olabilecektir.

\section{Senaryo veya Sahte Denetim Kavramı}

Senaryo denetim olgusunun temelinde yer alan senaryosal düşünmenin tarihçesi ilk çağlara kadar uzanmaktadır. Geçmişten günümüze kadar olan süreçte, organizasyonlar ve bireyler daima "ya gerçekleşirse”, "ya olursa” vb. gibi senaryoların sonucunda kendilerinin veya organizasyonlarının başlarına gelebilecek istenmeyen, zor durumlara karşı ne yapabilecekleri konusunda önceden düşünme ve aksiyon alma baskısı altında hissetmişlerdir. Organizasyonların ve bireylerin doğasında var olan farklı kötü senaryoları önceden düşünme ve planlama güdüsünün aksiyon alma eylemi ile birleşimi ise tarihsel süreç içerisinde senaryosal düşünme eylemine stratejik bir boyut katmış ve planlanan söz konusu senaryolar stratejik düşünmede kullanılan bir araç haline dönüşmüştür. Senaryo planlaması; işletmelerin karşılaşabilecekleri sorunları ortaya çıkarmak ve anlamak için kullanılabilen bir karar verme araçlarından biridir. Senaryo planlama, iletişim içinde farklı 
düşünmeyi içeren katılımcı, stratejik yönetim yaklaşımıdır. Uygulanan senaryolar ile elde edilen sonuçlar bireyleri ve işletmeleri çeşitli alternatif gelecekler için hazırlar. Senaryo planlama etkili kullanıldığında; örgütsel bir radar gibi çalışarak işletmede ortaya çıkabilecek ve işletmenin aleyhine gelişebilecek olası sinyalleri tarar. (Chermack, 2011: 10)

Senaryosal düşünme; denetim biliminde de yer verilen, faydalanılan bir kavramdır. Orijinal adı "Mock Audit" olan bu terim Türkçe'ye senaryo denetimi, senaryosal denetim, prova denetimi, sahte denetim gibi farklı ifadelerde çevrilebilir.

Senaryo denetimi; "gerçek veya resmi bir denetimin tüm prensiplerini içeren ve temelde işletmeler tarafindan ileride karşı karşıya kalınabilecek riskler ile gerçek bir denetim faaliyeti sonucunda maruz kalnabilecek çeşitli para cezası veya ücretleri önceden engellemek için uygulanan bir iç değerlendirme denetimi” olarak tanımlanabilir. (Business\&Industry Connection, [BIC], 2019) Senaryosal denetim uygulanırken, işletme, denetimin tüm sürecini yansıtacaktır. Bu; çalışanlara işletmenin yer aldığı sektör gereksinimlerine göre değişebilen denetim protokollerine aşina olmasını sağlar.

Senaryo denetimi; geleceğe dönük bir denetim yöntemi olmakla beraber yaratıcı bir perspektif kazandırmakta tüm denetim türlerinde uygulanabilmektedir. Gerçek bir denetim olmayan senaryo denetimini faydalı bir hale getirmek için mümkün olduğunca gerçekçi davranılmalıdır. Net bir plan oluşturulmalı ve senaryosal denetçiye aynen gerçek olana davranıldığı gibi davranılmalıdır. Senaryo denetiminden en iyi sonuç almak için tüm süreç boyunca senaryoya dahil olan çalışanlar üstlendiği rolü devam ettirerek karakterinde kalmalıdır. (Smartpharmaconsulting, [Smart], 2010)

Senaryo denetimler çoğunlukla işletmelerdeki standart iş süreçlerinin etkinlik ve verimliliği ile yasal politika ve prosedürlere uygunluğunu test etmeye yönelik olarak uygulanmaktadır. Bu yüzden senaryo denetimlerin genellikle uygunluk denetimleri ve faaliyet denetimlerinde kullanıldığını söyleyebiliriz.

\section{Senaryo Denetim Modelleri ve Senaryo Denetim Süreci}

Denetim bilimi açısından farklı denetim senaryolarının çeşitli stratejilerle birleştirilerek kullanılması senaryo denetimler için modeller geliştirilmesini sağlamıştır. Diğer bir deyişle denetçiler tarafından senaryoların, stratejik düşünme için tasarlanmış bir araç olarak farklı şekillerde kullanılması ihtiyacı, denetim modellerinin ortaya çıkışını sağlamıştır. Buna göre senaryo denetim modelleri, aslında ilk çağlardan günümüze kadar gelen ve literatürde "senaryo planlamacı yaklaşım" olarak adlandırılan söz konusu senaryosal stratejik düşünme yaklaşımına göre şekillendirilmiş prototip özellikteki denetim teknikleri olarak da nitelendirilebilirler.

Uygulamada senaryo denetimlerinde kullanılan iki farklı senaryo denetim modeli bulunmaktadır. Bunlar; "senaryo kurma modeli (scenario building)" ve "rüzgâr tüneli (wind tunnelling)" modelleridir. Senaryo kurma modeli, denetçiler tarafindan denetlenen organizasyonların ve çevresinin gelecekte karşılaşabileceği olası durum ve koşulları ile organizasyonların içsel olarak sabit durum ve koşullarına yönelik az sayıda (2 ile 4) senaryo kurgulamasının yapıldığı modeldir. Bu modelin amacı, organizasyonların anlık durumunu daha somut olarak incelemek ve geleceğe yönelik stratejik vizyon perspektifini genişletmektir. Rüzgâr tüneli modeli ise geleceğe yönelik kurgulanmış farklı kötü senaryolar karşısında geliştirilmiş spesifik stratejilerin nasıl çalışacağını ve bu stratejilerin söz konusu senaryolar karşısında ne kadar başarılı olabileceğini test etme amacına yönelik olarak geliştirilmiş bir modeldir. Rüzgâr tüneli modeli; organizasyonlar açısından yönetilmesi gereken riskler, ihtiyaç duyulabilecek olası yetenekler, istenen sonuçları hızlandıracak gelişmeler ile istenen sonuçları engelleyecek tehdit ve engeller ile istenen sonuçların devamlılı̆̆ını sağlayacak unsurların yeniden düşünülmesini gerektirmektedir. Bu model, senaryo kurma modeline göre daha detaylı bir yöntemdir. (Ling, 2003: 448)

Senaryo denetimler kapsamında hangi model uygulanırsa uygulansın bir senaryo denetimi özünde mutlaka denetim organının gelecektekiçevreye yönelik olarak kendi senaryolarını oluşturmasını, kurmasını veya üretmesini gerektirmektedir. Bununla birlikte uygulamada bu işlev aynı zamanda denetim modelleri kapsamında oluşturulan denetim senaryolarının gelecekle ilgili olarak öngörülen veya beklenen ortak yargılarda bir değişim yaratmasını da içermektedir. Çünkü, denetimde senaryo planlamacı yaklaşım, geleceğe göre organize olan ve tasarlanan bir denetim alanının ötesinde daha önce hiç alışılmadık bir durum veya ortama karşı en iyi planlarla karşılık verebilme yeteneğine sahip olmayı gerektirmektedir. 
(Ling, 2003: 446) Bu anlamda senaryo planlamacı denetçiler tarafından "rüzgâr tüneli" olarak adlandırılan senaryo denetim modelinin, senaryo denetimlerde daha geniş bir uygulama alanı bulduğu ve daha fazla tercih edildiği söylenebilir.

Senaryo denetimleri kapsamında tercih edilen denetim modelinin merkezinde "senaryolaştırma", "planlama" ve" strateji geliştirme" özellikleri bütünleşik olarak yer almalı ve denetim modelleri içerisinde birbirleriyle senkronize şekilde uygulamaya geçirilmelidir. Bu yüzden senaryo denetim süreci, normal bir denetim çalışmasına göre bazı farklılıkları içerebilmektedir. Bilindiği üzere normal bir denetim süreci; müşteri işletmenin kabulü ve denetim anlaşmasının yapılması, denetimin planlaması, denetimin yürütülmesi (test etme) ve denetimin raporlanması olmak üzere dört temel aşamadan oluşmaktadır. Bu aşamaları, senaryo denetimler açısından değerlendirildiğinde, standart bir denetim sürecinin ilk aşaması olan müşteri işletmenin kabulü ve denetim anlaşmasının yapılması aşamasının senaryo denetimlerde kısmen ortadan kalkacağı sonucuna varılabilir. Bunun sebebi, senaryo denetimlerin ağırlıklı olarak uygunluk denetimlerinde kullanılan kurum içi değerlendirme çalışması niteliğinde olması ve gerçek bir denetim olmamasıdır. Dolayısıyla denetçiler veya denetim firması açısından sözleşmeye bağlanmış şekilde sorumluluk doğurabilecek gerçek bir denetim söz konusu olmadığından, denetim sözleşmesinin kabulü açısından müşteri işletmenin kabulünün getirebileceği riskleri değerlendirmeye yönelik uygulanacak prosedürlere ve çalışmalara da ihtiyaç bulunmamaktadır. Nitekim senaryo denetimler çoğunlukla eğer işletmenin kendi sektör uzmanlığı varsa kendisi ya da işletmenin iç denetçileri tarafından, yoksa dışarıdan sağlanan çeşitli bağımsız danışmanlık firmaları tarafından yapılmaktadır. Buna göre senaryo denetimlerin uygulanacağı işletme ve senaryo denetimini uygulayacak taraflar (işletmenin kendisi, iç denetçiler, bağımsız danışmanlık firmaları vb. gibi) arasında, standart bağımsız denetim sürecindeki anlamına eş değer bir müşteri işletme ve denetim firması ilişkisi bulunmadığı söylenebilir. Bununla birlikte normal bir denetim sürecinde bu aşamanın kapsamına giren müşteri işletmedeki çalışanlarla tanışılması, müşteri işletmenin işletme için süreçlerinin incelenmesi vb. gibi faaliyetler senaryo denetim sürecinin iş akışı kapsamında birebir uygulanmaktadır.

Denetim sürecinin ikinci aşamasını oluşturan planlama; denetçilerin denetim görüşüne esas oluşturacak denetim faaliyetlerinin nasıl yürütüleceğinin belirlenmesini ifade etmektedir. Denetim konusunun denetim sahalarına ayrılması, denetçilerin denetim sahalarına dağıtılarak görevlendirilmesi, denetim sahalarında uygulanacak prosedürlerin ve işlerin belirlenmesi ve denetimin maliyetinin ve zamanlamasının ayarlanması denetimin planlaması aşamasının kapsamına girmektedir. (Güredin, 2014: 184) Senaryo denetimler açısından ise planlama aşaması normal bir denetim sürecinden farklı olarak senaryo ağırlıklı bir planlama faaliyetini ifade etmektedir. Senaryo denetim faaliyetleri kapsamında ortada gerçek bir denetim bulunmadığından, denetçilerin görevleri, denetimde yürütülecek çalışmalar, denetimin zamanlaması ve kapsamı da tasarlanan senaryo veya senaryolara göre planlanmaktadır. Diğer bir deyişle senaryo denetimlerinde öncelikle denetime konu oluşturacak bir senaryo oluşturulmakta ardından planlama aşamasında söz konusu senaryo detayları şekillendirilerek planlanmaktadır.

Denetim sürecinin üçüncü aşamasını oluşturan denetimin yürütülmesi (test etme) aşamasının standart prosedürleri, senaryo denetimlerde de aynen geçerli olmaktadır. Buna göre senaryo denetimler kapsamında ortada denetlenmesi gereken gerçek bir olgu varmış gibi davranılarak, denetim prosedürleri test edilmekte ve denetim riskleri değerlendirilmektedir. Ayrıca senaryo denetimlerde yürütme aşamasında, normal bir denetim sürecindeki yürütme aşamasından farklı olarak geleceğe yönelik olası kötü senaryolar için geliştirilen stratejik önlemler ve prosedürlerin başarısı da önceden test edilerek ölçülmektedir. Benzer şekilde denetimin raporlanması aşaması da senaryo denetimler kapsamında birebir uygulanmakta ve gerçek bir denetim faaliyeti olsaydı denetim raporunda yer alabilecek potansiyel hususlar senaryo denetim çalışmaları ile önceden tespit edilerek işletmelere raporlanmaktadır.

Yukarıda açıklanan bilgiler doğrultusunda senaryo denetim sürecinin aşamaları aşağıdaki gibi sıralanabilir;

1) Denetim senaryosu veya senaryoları hazırlama ve analiz etme

2) Denetim senaryolarının planlanması

3) Denetim senaryolarının yürütülmesi ve analiz edilmesi (test etme) 
4) Denetim senaryolarına yönelik stratejiler ve çözüm önerilerinin geliştirilmesi

5) Denetim senaryosu sonuçlarının raporlanması

Bir senaryo denetim sürecinin normal bir denetim sürecinden en önemli farkı, standart denetim prosedürlerine ek olarak senaryo hazırlama ve analiz etme prosedürünü de içermesidir. Senaryo denetimlerin ilk aşamasını oluşturan senaryo hazırlama ve analiz etme aşamasında bu senaryonun, denetlenen işletmenin standart operasyonel prosedürleri dikkate alınarak tasarlanması ve analiz edilmesi oldukça önemlidir.

Senaryo denetimler, denetim süreci açısından değerlendirildiğinde, senaryo denetimlerin niteliği uyarınca denetim faaliyetlerinin ve denetim sürecinin ilk elden gözlemlenmesine olanak sağladığı görülmektedir. Senaryo denetimler sayesinde, gelecekteki denetim faaliyetlerinin tasarlanması, planlama aşamasının geliştirilmesi veya değiştirilmesi için önemli bilgiler sağlanabilmekte, denetim çalışmaları için denetçilerin potansiyellerinin iyi olup olmadığı ile geleceğe yönelik geliştirilen prosedürlerin başarılı olup olmadığı konusunda ise önemli ipuçları elde edilebilmektedir. Bunun en büyük sebebi, senaryo denetimlerin gerçek bir denetimde olabilecek şekilde bağımsız ve stratejik düşünme, planlama, öneri ve çözüm geliştirme, raporlama vb. gibi olanakları sunarak operasyonel anlamda denetçilere gerçekçi bir denetim deneyimi kazandırması ve bu alandaki deneyimlerini kullanabilme şansı vermesidir. (Clay, 1996: 26) Uygulamada iç denetçiler veya bağımsız danışmanlar tarafından yapılan senaryo denetimler, genellikle 4 ile 5 gün arasında sürmektedir.

\section{Senaryo Denetim, Öz Denetim, Sürpriz Denetim ve Sürekli Denetim İlişkisi}

Senaryo denetim, öz denetim, sürpriz denetim ve sürekli denetim kavramları zaman zaman birbirine karıştırılan benzer kavramlar gibi görünmekle birlikte denetim bilimi açısından her bir kavram aslında farklı bir anlamı ifade etmektedir. Senaryo veya prova denetim; "işletmelerin operasyonel süreçlerindeki uygunsuzlukları, hileye açık alanları ve kontrol eksikliklerini gerçek bir denetimden önce tespit etmek böylelikle muhtemel maliyet ve zararlardan kaçınmak amacıyla yapılan ve gerçek bir denetimdeki tüm süreçlerin senaryolar üzerinden uygulanmasına dayalı olarak gerçekleştirilen bir denetimi ifade etmektedir. Bir senaryo denetimin en belirgin özelliği ortada henüz denetime konu bir olgu yok iken denetime konu olabilecek bir kurgu veya kurgular üzerinden denetim fonksiyonunun yürütülmesidir. Senaryo denetimlerle çok karıştırılan öz denetimler ise senaryolar üzerinden yapılmamaktadır, dolayısıyla kurgusal nitelikte değildir. Öz denetim; işletmelerin geçmiş süreçlerinin öngörülen yasa ve yönetmeliklere uygunluklarını ölçmek amacına yönelik olarak dışarıdan veya işletmenin içerisinden bir ekip tarafından yürütülen denetimdir. Buna göre öz denetimlerde denetim fonksiyonu, senaryo denetimlerin aksine geçmiş süreçler üzerinden yani gerçekte mevcut bulunan bir olgu üzerinden yürütülmektedir. Kendi kendine denetim olarak da nitelendirilen öz denetimlerin temel amacı, işletme içerisindeki potansiyel tehditleri bulmak ve yasal denetimlerden önce denetim sorunlarını anlamak için zaman kazanmaktır. Senaryo denetimlerde ise temel amaç, gerçek veya resmi denetim faaliyetleri için ihtiyaç duyulabilecek konularda (gerçek bir denetimde açıklanmasına ihtiyaç duyulabilecek potansiyel durumlar, istenebilecek denetim kantları, istenecek bilgi ve belgeyi temin edecek, hazırlayacak veya açıklayacak personelin kim olacağı, tespit edilebilecek denetime aykırı durumlar vb. gibi) işletmenin hazırlıklı olmasını sağlamaktır. (Bodell, 2009: 15)

Sürpriz denetim; denetime konu olan müşteri işletmenin çalışanlarından habersiz olarak yapılan ve işletmeler tarafından genellikle hile karşııtı bir kontrol aracı olarak kullanılan denetim türüdür. Sürpriz denetimin diğer denetimlerden en önemli fark1, sürpriz denetimlerde denetim fonksiyonunun işletme içerisinde haber verilmeden yürütülmesidir. (Özdemir, 2013: 68-69) Sürpriz denetimlerde işletme içerisinde bir denetim faaliyetinin yürütüldüğünden işletme çalışanlarının haberlerinin olmaması işletme içerisindeki hırsızlık, suistimal vb. gibihilelerin ortaya çıkarılmasını da kolaylaştırmaktadır. Bunun sebebi işletmelerde hile yapan veya yapma hazırlığ içerisinde bulunan işletme çalışanlarının, denetimden habersiz olmaları halinde yaptıkları hileyi saklamak için uğraşma ihtiyacı duymamaları veya saklamak için yeterli zamanı bulamamalarıdır. Sürpriz denetimler bu özellikleri sebebiyle işletmelerde hile olayları ile mücadelede kullanılabilecek en etkili araçlardan biridir ve en önemli faydaları, hilekâr işletme çalışanlarında yakalanma algısını oluşturmalarıdır. İşletmelerde sürpriz denetimin devam ettiği süre boyunca hilelerin ortaya çıkarılması 
kolaylaşabilmektedir. (Johnston, Wademan ve Lamberts, 2010: 2-3) Bununla birlikte uygulamada sürpriz denetimlerin işletmeler tarafından yeterli oranda kullanılmadığı görülmektedir. Uluslararası Hile İnceleyicileri Derneği (ACFE) tarafindan yayınlanan 2020 yılı Global Hile ve Yolsuzluk Raporuna göre hile ile mücadelede sürpriz denetim yönteminin, işletmelerin yalnızca \%38'i tarafından kullanıldığı tespit edilmiştir. (Association of Certified Fraud Examiners, [ACFE], 2020) Sürpriz denetimlerin senaryo denetimlerle olan ilişkisi incelendiğinde, sürpriz denetimler de tıpkı öz denetimler gibi senaryo denetimlerden farklı olarak gerçekte var olan bir sürecin üzerinden gerçekleştirilmektedir. Ayrıca senaryo denetimler haber verilerek uygulanırken sürpriz denetimler habersiz şekilde yapılmaktadır. Bununla birlikte sürpriz denetimlerin uygulamada bazen senaryo denetimlerle birlikte kullanıldığı da görülmektedir. Diğer bir deyişle işletme içerisinde normalde haber vererek uygulanan senaryo denetimler, daha etkin olması için habersiz şekilde gerçekleştirilerek "sürpriz senaryo denetimlere" dönüşebilmektedir. (Opiela, 2002: 56)

Sürekli denetim; "işletmelerin sürekli kontrol mekanizmasına odaklı olarak işletme faaliyetlerinin ve süreçlerinin iç denetçiler tarafından sürekli şekilde analiz edildiği denetim faaliyeti” şeklinde tanımlanabilir. (Gonzalez ve Hoffman, 2018: 225). Sürekli kontrol değerlendirmesi ve sürekli risk değerlendirmesi, sürekli denetimin temel unsurlarını oluşturmaktadır. İşletmelerde sürekli denetim faaliyeti ile çeşitli teknolojiler aracılığıyla işletmelerin verileri sürekli olarak denetlenmekte böylelikle işletme içerisinde herhangi bir kontrol zayıflığına veya hileye meydan verilmemesi amaçlanmaktadır. (Vardar, 2019: 85-86) Öz denetim ve sürpriz denetimde olduğu gibi sürekli denetimlerde işletme içerisinde var olan gerçek süreçler üzerinden yürütülmektedir ve herhangi bir senaryo denetimini kapsamamaktadır. Bununla birlikte sürekli denetim faaliyeti, sürekle izleme ve gözetim felsefesine dayalı olduğu için senaryo denetimlerin, sürekli denetim faaliyetlerinin bir parçası olarak kullanılabileceği söylenebilir. İşletme içerisinde gelişmiş teknolojilerin kullanımına dayalı olarak yürütülen sürekli denetim faaliyetlerinin başarı olabilmesi için doğru teknolojinin seçilmesi, uygun kültürün oluşturulması, eksikliklerin tespit edilmesi, önemli kriterlerin tanımlanması vb. gibi adımlara ek olarak sürekli denetim süreci içerisinde uygun suistimal tespit ve önleme senaryolarının işletmelere özel şekilde tasarlanmasına da yer verilmesi gerekmektedir. (Tamay, 2010:15)

\section{Senaryo Denetimlerin Avantaj ve Dezavantajları}

Senaryo denetimlerin işletmelerde muhasebe sistemlerinin güvenilirliğinin sağlanması, hırsızlık, hileli finansal raporlama, sahtekârlık vb. gibi hile ve usulsüzlüklerin önlenmesi veya azaltılması, yakın olası gelecekte yaşanabilecek durumların öngörülebilir kılınması konusunda pek çok faydası bulunmaktadır. Bu faydalara ek olarak senaryo denetimlerin sadece işletmeler açısından değil, senaryo denetim faaliyetini yürüten denetçiler açısından da sağladığı faydalar söz konusudur. 1996 yılında Raymond J.Clay Jr tarafından Amerika’daki Kuzey Teksas Üniversitesi iç denetim lisans öğrencileri üzerinde yapılan bir araştırma, senaryo denetimlerin denetçiler açısından eğitici ve öğretici yönünü açıkça ortaya koymuştur. Araştırmada öğrenciler 15'erli şekilde 3 farklı gruba ayrılmış ve her bir gruba organizasyonların çoğunda yaygın olarak bulunan temel operasyonel alanları temsil eden bir konu verilmiştir. Organizasyonların yapısının nasıl olacağı, denetim konu olabilecek verilerin ve denetimde sorulması gereken iç denetim sorularının neler olabileceği ise tamamen öğrencilerin hayal gücüne bırakılmıştır. (Clay, 1996: 25) Özünde senaryo bir iç denetimin uygulandığı bu araştırma; denetçilerin kendini geliştirmesi, güçlü ve zayıf yanlarını tespit etmesi ve yeni kazanımlar elde etmesi konusunda onlara gerçek bir denetim deneyimi sunarak mevcut yeteneklerini test etme konusunda önemli bir fırsat sağlamıştır. Senaryo denetimlerin işletmeler ve denetçiler açısından başlıca avantajları aşağıdaki gibi sıralanabilir;

- İşletmelere, mevcut iş süreçlerinin durumunu gözlemleme ve operasyonel sistemlerindeki kontrol açıklarını veya eksikliklerini gerçek denetimlerden önce tespit ederek düzeltme fırsatı vermesi

- İşletmelerin standart operasyonel süreçlerinin geliştirilmesine ve operasyonel risk yönetiminin iyileştirilmesine yardımcı olması

- İşletmelerin kriz ve belirsizlik durumlarında yakın olası geleceğe yönelik programların oluşturup politikalar tasarlaması, kestirimsel bir değerlendirme yapmasına olanak vermesi ve işletmelerin uygunluk politikalarının yönetimi açısından proaktiflik sağlaması 
- İşletmelerde suistimal ve yolsuzlukların ortaya çıkarılmasına ve azaltılmasına yardımcı olması dolayısıyla hile ile mücadelede etkin bir araç olarak kullanılabilmesi

- Denetçilere gerçek denetimlerden önce bir ön hazırlık fırsatı vermesi

- Denetçilere, operasyonel anlamda gerçekçi bir deneyim kazandırması ve deneyimlerini kullanabilme şansı vermesi

- Denetim faaliyetlerinin ve denetim süreçlerinin ilk elden gözlemlenmesine olanak tanıması

- Denetim risklerinin yönetilmesine olanak vermesi

- Gelecekteki denetim faaliyetlerinin tasarlanması, ön hazırlık/planlama aşamalarının geliştirilmesi veya revize edilmesi için somut bir kaynak sağlaması

- Diğer denetimlerle birlikte kullanılabilmesi ve sınırlı denetim alanlarını genişleterek yaratıcılığı arttırması

Senaryo denetimlerin işletmeleri ilgilendiren en önemli faydası ise işletmelerde ileride meydana gelebilecek potansiyel uygunsuzlukları henüz ortada böyle bir durum yok iken şimdiden tasarlanan senaryolarla öngörmesi ve bunlara karşı çeşitli stratejiler ile çözüm önerileri geliştirmesidir. Senaryo denetimlerin bu özelliği sayesinde işletmeler, özellikle yasal denetimler sonucunda tespit edilen uygunsuzluklar sonucunda maruz kalabileceği para cezalarından veya büyük kayıplara yol açabilecek hile risklerinden kaçınabilmektedir. (Lenok, 2009:4) Uygulamada pek çok işletme aslında aylarca sürebilecek gerçek denetim çalışmalarının sonucunda ortaya çıkabilecek para cezalarına maruz kalmamak için senaryo denetimleri uygulamaktadir.

Senaryo denetimlerin hem işletmeler hem de denetçiler açısından çeşitli faydaları bulunmakla birlikte bazı dezavantajları da söz konusudur. Bir senaryo denetim uygulaması işletmeler ve denetçiler açısından zaman ve emek maliyetine sebep olmaktadır. Senaryo denetimlerin doğası gereği oluşturulması veya üretilmesi gereken senaryolar, ayrıca bir yaratıcılığı ve düşünmeyi dolayısıyla senaryolar üzerinde ciddi bir emek ve zaman harcamayı gerektirmektedir. Aynı zamanda senaryo denetimler geleceğin tasarlanmasını da içerdiğinden sektörün de çok iyi bilinmesini, sektörde oluşabilecek kriz ve belirsizliklerin öngörülmesini ve bu öngörülerin mantıksal temeller üzerinde oturtulmasını gerektirmektedir. İşletmelerin ve işletmedeki iç denetçilerin bu konularda uzmanlığının bulunmaması durumunda dışarıdan bağımsız danışmanlık firmaları tarafından senaryo denetim hizmetinin alınması, işletmelere ayrıca bir maliyet getirmektedir. Bununla birlikte gerçek bir denetim faaliyeti sonucunda ortaya çıkabilecek para cezalarının, tespit edilecek hile olaylarının veya denetim raporunda yer alabilecek olumsuz görüşlerin maliyetinin, işletmede senaryo denetim uygulamanın işletmeye getireceği maliyetten çok daha fazla olabileceği düşünüldüğünde, senaryo denetimlerin aslında maliyet oluşturmaktan çok işletmelerin kârlılığına katkı sağladığı söylenebilir.

\section{Senaryo Denetimlerinin Önemi}

Senaryo denetimleri, işletmelerde arzu edilen bir kurumsal kültürün oluşturulması, işletme içi kültürel süreçlerin iyileştirilmesi, işletme içi standart iş ve süreçlerin iyileştirilmesi, örgütsel karmaşıklıkların önlenmesi, muhasebe sistemlerinin güvenilirliğinin sağlanması, hile ve usulsüzlüklerin önlenmesi, denetim faaliyetlerinin etkinliğinin arttırılması, geleceğe yönelik politika ve prosedürler geliştirilmesi, gelecekle ilgili stratejik çalışmalar yapılması, kriz ve belirsizlik durumlarına karşı hazırlıklı olunması vb. gibi pek çok konuda önem arz etmektedir.

Çalışmamızda senaryo denetimlerinin önemi, denetim bilimi ve muhasebe denetimi açısından değerlendirilmiştir. Dar ve eski anlamıla muhasebe denetimi; "muhasebe kayıt ve belgeleri üzerinden yapılan denetim” şeklinde tanımlanabilir. (Güvemli ve Özbirecikli, 2011:168) Buradaki tanım daha çok vergisel amaçlı olarak yasal yetkili kişiler tarafından yapılan sınırlı bir denetimi ifade etmektedir. Günümüzde denetim biliminin geldiği nokta dikkate alındığında muhasebe denetiminin dışarıdan bağımsız kuruluşlar tarafından yapılan daha geniş kapsamlı bir değerlendirmeyi içerdiği açıktır. Buna göre en geniş tanımıyla muhasebe denetimi; “herhangi bir ekonomik birime veya döneme ait bilgilerin, önceden saptanmış ölçütlere 
uygunluk derecesini araştırmak ve bu konuda rapor düzenlemek amaciyla bağımsız bir uzman tarafindan yapılan kanıt toplama ve değerlendirme süreci" olarak ifade edilebilir. (Bozkurt, 2010:23)

Yukarıdaki tanımda geçen denetime konu bilgiler, işletmelerin muhasebe sistemleri tarafından üretilen finansal bilgileri ifade etmektedir. Muhasebe sistemlerinin ürettiği finansal bilgilerin gerçek bir denetimde esas alınacak olan ölçülere uygunluk derecesinin önceden ölçülmesinde ve değerlendirilmesinde senaryo denetimler etkin bir rol oynamaktadır. Senaryo muhasebe denetimleri sayesinde işletmelerin muhasebe sistemlerindeki mevcut hatalar, hile veya usulsüzlüklere fırsat ortamı yaratabilecek açık alanlar ve kontrol eksiklikleri önceden tespit edilerek telafi edilebilmektedir. Buna ek olarak geleceğe yönelik potansiyel hataların, hile ve usulsüzlük olaylarının ve sistemsel zafiyetlerin neler olabileceği de farklı senaryolar içerisinde tasarlanmakta ve söz konusu senaryolara karşı şimdiden çözüm önerileri geliştirilerek stratejik aksiyonlar alınmaktadır. Diğer bir deyişle senaryo denetimler aracılı̆̆ıla gelecekte muhasebe sistemlerinde yaşanabilecek ve gerçek bir denetimde sorun oluşturabilecek hususlar öngörülebilir hale getirilmektedir. Böylelikle hem muhasebe denetimlerinin etkinlik ve verimliliği arttırılmakta hem de denetimde proaktiflik sağlanabilmektedir.

Senaryo denetimler, muhasebe sistemleri içerisindeki hile ve usulsüzlükler ile mücadele konusunda da etkin bir araç olduğu için aynı zamanda muhasebe sistemlerinin güvenilirliği de arttırılabilmektedir. Tüm bunlar ise işletmeler açısından, gerçek bir denetim sonucunda muhasebe sistemlerinde tespit edilen çeşitli uygunsuzluklar sebebiyle maruz kalınabilecek para cezası, olumsuz denetim görüşü alma, hile kaybına uğrama vb. gibi finansal ve finansal olmayan nitelikteki olumsuz sonuçları önlemektedir. "İ̧̧letmeler senaryo denetim masrafları için bütçe ayırabilir ancak, gerçekleşmiş yasal bir para cezası veya ücretler için bütçe ayıramaz" sözü senaryo denetimlerin muhasebe denetimi açısından taşıdığı önemi açıkça ortaya koymaktadır. (Lenok, 2009:4)

\section{Sonuç}

Geleceğe yönelik kaos ve belirsizlik ortamı, işletmelerde geleceği planlama ve tasarlama eğilimini her geçen gün arttırmaktadır. Her şeyin çok hızlı şekilde değiştiği ve beklenmedik durumların sıklıkla meydana geldiği bir çevrede, işletmelerin sürekliliklerini sağlayabilmeleri için geleceği kurgulayabilme yani senaryosal düşünme yeteneğine sahip olmaları bir gereklilik olarak karşımıza çıkmaktadır. Nitekim işletmeler tarafından kriz ve belirsizlik ortamına karşı verilen savaşta kullanılan yapay zekâ uygulamaları ve 3D teknolojilerin de senaryo kurgulama yaklaşımına dayalı olarak geliştirildiği görülmektedir. Böyle bir ortamda muhasebe tahmini bilgi sistemlerinin ürettiği gerçekleşmiş finansal bilgi ve verilerden ziyade, bu finansal bilgi ve verilerin tahmini tarafı çok daha fazla önemli hale gelmiştir. Bu noktada muhasebe sistemlerinin güvenilirliğini değerlendiren denetim biliminin etkin ve faydalı olabilmesi ancak, denetime konu olabilecek finansal durum ve olayları bir adım önceden kurgulaması ve bunların işletmenin finansal verileri üzerinde yaratabileceği potansiyel etkileri farklı senaryolar üzerinden analiz edip değerlendirmesi ile mümkün olabilecektir.

Geleneksel denetim anlayışlarından farklı olarak senaryo denetimler, kriz ve belirsizlik ortamlarında da denetim faaliyetlerinin etkinliğinden ödün vermeden uygulanabilir olma özelliğine sahip bulunmaktadır. Ayrıca senaryo denetimlerin diğer denetim türleriyle birlikte kullanılabilmesi işletmeler açısından kullanım kolaylığı sağlamaktadır. Senaryo denetimlerin bu özelliği sayesinde işletmelerde "walkthrough" adı verilen baştan sona süreç denetimleri ile uygunluk ve faaliyet denetimleri, senaryo denetimlerle birleştirilerek senkronize olarak uygulanabilmekte ve günümüz koşullarına uygun hale getirilebilmektedir.

Senaryo denetimlerin avantajları ve dezavantajları başlığı altında ayrıntılı şekilde açıkladığımız üzere senaryo denetimlerin hem işletmeler hem de denetim fonksiyonu açısından pek çok faydası bulunmaktadır. Buna rağmen uygulamada işletmeler tarafından senaryo denetimlerin, çeşitli maliyet endişeleri sebebiyle yeterince kullanılmadığı ve genellikle ihmal edildiği görülmektedir. Aynı zamanda senaryo denetim kavramına yönelik çalışmalar, literatürde de oldukça sınırlı seviyededir. Maliyet endişeleri kadar bu durumun da senaryo denetim olgusunun bilinirliğinin yetersiz olmasına, yeterince anlaşılmamasına dolayısıyla uygulama alanı bulamamasına neden olduğu söylenebilir.

Günümüz Dünyasında senaryo denetimlerinin önemi konusunda işletmelerde bir farkındalık oluşturulmasına ihtiyaç 
bulunmaktadır. İşletmelerde senaryo denetimlerinin gerekliliğine ve önemine yönelik bir algının oluşturulması ve işletmelerin bu konuda bilinçlendirilmesi için literatürde ve uygulamada senaryo denetim konusunda yeni çalışmalara yer verilebilir. Böylelikle senaryo denetimlerin bilinilirliğinin sağlanarak senaryo denetimlerin kullanımı alanları da genişletilebilir.

Hakem Değerlendirmesi: Dış bağımsız.

Çıkar Çatışması: Yazarlar çıkar çatışması bildirmemiştir.

Yazar Katkıları: Çalışma Konsepti/Tasarım- A.A.O., N.G.B.; Veri Toplama- N.G.B.; Yazı Taslağı- A.A.O., N.G.B.; İçeriğin Eleștirel İncelemesi- A.A.O., N.G.B.; Son Onay ve Sorumluluk- A.A.O., N.G.B.

Finansal Destek: Yazarlar bu çalışma için finansal destek almadığını beyan etmiştir.

Teşekkür: Makalenin yayın sürecindeki desteklerinden ötürü Prof. Dr. Aslı Türel’e teşekkür ederiz.

Peer-review: Externally peer-reviewed.

Conflict of Interest: The authors have no conflict of interest to declare.

Author Contributions: Conception/Design of Study- A.A.O., N.G.B.; Data Acquisition-N.G.B.; Drafting Manuscript- A.A.O., N.G.B.; Critical Revision of Manuscript- A.A.O., N.G.B.; Final Approval and Accountability- A.A.O., N.G.B.

Grant Support: The authors declared that this study has received no financial support.

Acknowledgement: The authors would like to thank Prof. Dr. Aslı Türel, for her support in the publication process of the article.

\section{Kaynaklar}

Bodell, T., (2009). Self-audits, mock audits and assessments: are you prepared for a regulatory investigation ?. Electric Light \& Power (ELP), 87 (3), 15.

Bozkurt,N., (2010). Muhasebe denetimi. İstanbul: Alfa Yayınlar1

Clay, RJ., (1996). A mock operational audit based on library research. Managerial Auditing Journal, 11 (5), 26.

Gonzalez,G., Hoffman,V.B., (2018). Continuous auditing's effectiveness as a fraud deterrent. Auditing: A Journal of Practice \& Theory. 37 (2), 225.

Güredin, E., (2014). Denetim ve güvence hizmetleri. İstanbul: Türkmen Kitabevi.

Güvemli,O., Özbirecikli,M., (2011). Türkiye'de bağımsız muhasebe denetiminin gelişim süreci. Muhasebe ve Finans Tarihi Araştırmaları Dergisi, 168.

Johnson, J., Wademan,D., ve Lamberts,S., (2010). Accounting\&performance measurement: surprise audits deter fraud. Controller's Report, 8, 2-3.

Lenok, N. (2009). Considering a mock audit...reasons why you should. Managing Imports\&Exports, 1 (57), 4.

Ling, T., (2003). Ex ante evaluation and the changing public audit function-the scenario planning approach. Journal of Evaluation. 9(4), 446-448.

Opiela, N., (2002). They’re here... how to survive an audit, Journal of Financial Planning, 56.

Özdemir, Ü.F., (2013). Bankalarda hile riski yönetimi ve bir uygulama. Marmara Üniversitesi, Sosyal Bilimler Enstitüsü, Doktora Tezi. Tamay,G. (2010). Sürekli denetim sürekli gözetim. KPMG Gündem, 3, 15.

Vardar,M.K., (2019). Hilenin önlenmesi ve ortaya çıkarılması: muhasebe meslek mensuplarının görüşleri üzerine nitel bir araştırma. Istanbul Üniversitesi, Sosyal Bilimler Enstitüsü, Yüksek Lisans Tezi.

Association of Certified Fraud Examiners (2020). Report to the nations-2020 global study on occupational fraud and abuse. https:// acfepublic.s3-us-west-2.amazonaws.com/2020-Report-to-the-Nations.pdf, (30.01.2021).

Business \& Industry Connection (2019). Mock audits: how they can help your company. https://www.bicmagazine.com/departments/hr/ mock-audits-disa/, (24.12.2021).

Smartpharmaconsulting (2010). How to perform a mock audit. https://smartpharmaconsulting.com/how-to-perform-a-mock-audit/, (01.02.2021). 